\title{
THE MORPHOLOGICAL FRAMEWORK OF THE CHINESE AND THE EUROPEAN DISTRICTS IN SURABAYA, 1787-2005
}

\author{
Timoticin Kwanda \\ Department of Architecture, Faculty of Civil Engineering and Planning \\ Petra Christian University, Surabaya-INDONESIA \\ Email: cornelia@petra.ac.id
}

\begin{abstract}
Recently, the phenomena of economic boom during the 1990s have led to the physical restructuring within the old centre of Surabaya. The changes is inevitable, thus the real issue is how to find the elements of persistent, constraining development to some degree that could be applied to influence future development. The objective of the research is to understand the impact of intervention, and to find the typo-morphological framework in the European and the Chinese quarters, from 1787 to 2005 for future development. A synchronic and a diachronic method is applied to understand the old town centre historical development, and the relationship between building type and urban fabric. The result shows three different degrees of persistent. The town plan of the Chinese and the European districts show a notable persistence. However the land utilization is less persistent especially in the European district such as the first and the second city wall were replaced by roads, and the first and the second fort were replaced by open space and residential uses. Finally, the buildings fabric shows a drastic change such as most of the nineteenth century Indische buildings have been replaced by the 1920s modern buildings.
\end{abstract}

Keywords: The morphological framework, the Chinese and the European district.

\section{INTRODUCTION}

The old centre of cities has rich cultural heritages such as historical buildings and traditions that had been formed for many decades. These cultural heritages are the distinct character of each city that differs from one city to another. Recently, new buildings and infrastructures were constructed to destroy these cultural heritages and to alter the morphology of this old district. These phenomena of new buildings intervention happened in many Asian cities, consequently cultural heritage of Asian' city is in danger of disappearing (Logan 2002).

These phenomena also happened in some cities of Indonesia, such as the cultural heritage in the old city of Surabaya that has been demolished under the impact of current rapid economic in 1990s. For example, in March 1995 a mall the so called Jembatan Merah Plaza was opened to replace the historic arsenal building in the old district of Surabaya (Dick 2003: 409). The changes or the disappearing of cultural heritage in the historic centre is inevitable, and thus the real issue is how to find the elements of persistent or the morphological framework, constraining development to some degree that could be applied to develop future development (Larkham 1990).

In this respect, the research deals with the morphological approach to understand the morphological framework in the old centre of Surabaya. The old centre consists of three areas such as the European quarter, the Chinese and the Ampel or the Muslim quarter. However the research will only focuses on the European and the Chinese quarters for these two quarters played an important role in the development of the city.

\section{Urban Typo-Morphology}

The study of urban form, otherwise known as urban morphology is rooted in the German-speaking countries that close to the mainstream of historical and urban geography (Larkham 1996). Urban morphology analyse a city's evolution from its formative year to its subsequent transformations. Moudon (1997) discusses the recent development of three schools of urban morphology that developed in England by M.R.G. Conzen in 1960, Italy by Saverio Muratori in 1959, and France by Philippe Panerai 1960s. The formation of the International Seminar on Urban Form (ISUF) in 1994 has bring together all of these schools. She argues that these schools provide the basis for an interdisciplinary field and the opportunity to establish common theoretical foundation. The common ground of these schools are first, cities can be 'read' and analyse via the medium of physical form; secondly there are three principles of morphological analysis such as urban form is defined by three fundamental physical elements such as buildings, plots or lots, and streets; thirdly urban form can be understood at different level of resolution such as 
building/lot, street/block, the city, the region; and finally urban form can only be understood historically since the elements undergo continues transformation and replacement.

This common ground, however, lack the element of the cosmic and dualistic tradition of morphological structure of the city in Indonesia as discussed by Gill (1995), Nas (1997) and Widodo (2004). Widodo (2004) analyzes Southeast Asian cities from the morphological point of view, as he traced the growth and development of coastal cities, especially the Chinese quarter in Southeast Asian cities from the 1st Century AD till the mid- $20^{\text {th }}$ century, such as the city of Banten, Batavia, Palembang, Semarang in Indonesia; Ayutthaya in Thailand, Melaka and Penang in Malaysia; and Singapore. This approach adopts an interdisciplinary approach to the materiality of culture from architecttural (morphology), sociological (activity, functional, anthropometrical), and philosophical (meaning, symbolical, mythological). This approach, however, would be appropriate when supported by relevant historical sources.

\section{Objectives and Significance}

The aim of the research is to identify the new elements of urban fabric, to understand the impact of intervention on the typo-morphological form of the city, and to find a typo-morphological framework for future development. Surabaya is the second largest city in Indonesia however scholarly research on typomorphological urban development is rare. Academic research in Indonesia has been mostly focussed on urban development and conservation of major cities in Java, such as Jakarta, Bandung (Siregar 1990; Harastoeti 2005), Semarang (Widodo 1988; Zahnd 2008), and Yogyakarta (Ikaputra 1993; Adishakti 1997, Zahnd 2008). Some academic researches on Surabaya had only focussed on social history (Frederick 1989) and socio-economic history (Dick 2003).

On the history of Surabaya, there are the trilogy of G.H. von Faber on Surabaya such as Oud Soerabaia (1931), Nieuw Soerabaia (1936), and Er werd een stad geboren (1953). The latest book on the same topic is Soerabaja 1900-1950: Havens, marine. stadsbeeld, port, navy, townscape edited by Diesen, J.R. van (2004), in order to fill the gaps, this book covers the period of 1900-1950 that has not been covered by G.H. von Faber. None of these books, however, deal with typo-morphology, and consequently this study on Surabaya will contribute to very scarce literature on typo-morphology. In short, the focus of study on the locus of the old district of Surabaya, and the method of typo-morphology for the research will shed light for new knowledge.

\section{RESEARCH METHOD}

This research explores typo-morphological methods to understand the historical development of the form of the buildings and the old town, and the locus of the research is the old centre of Surabaya. The old district of Surabaya is selected based upon its long historical period with a vast cultural heritages and has experienced a rapid transformation for decades. The data and resources are maps and photographs that obtained from various published sources such as books, archives, and newspaper. The maps are dated 1677, 1787, 1821, 1825, 1866, 1867, 1879, 1891, 1900, 1940 and 2005. ${ }^{1}$ The earliest date is set based upon the available 1787 map as the evidence of the earliest old centre's physical development, and 2005 is the latest date for the latest available map in 2005.

To understand the relationship between building type and urban fabric, and between typology and morphology, a synchronic and a diachronic analysis are used. Firstly, the synchronic analysis tries to understand the relationship between the primary elements of the urban fabric such as, plot (P), street (S), constructed space (CS), and open space (OS) such as squares, gardens, and courtyards. Levy (1999) develops a simplified model to understand these urban fabric relationships as two-way dialectical relationship in which morphological analysis is a reading of the table column by column examining the relationships one by one between: P/OS, P/CS, P/S, $\mathrm{P} / \mathrm{P}$, then S/OS. Some studies of this analysis examined the relationship of building type to the urban fabric pioneered by Caniggia in 1986 (Corsini 1997), and the town plan analysis examined the combination of three distinct of plan elements or 'plan-units' such as streets and their arrangement in a street system, plots and their aggregation in street blocks, and buildings or their block-plans (Conzen 1960).

Secondly, the diachronic analysis tries to explain the evolution and transformation of urban forms that

\footnotetext{
${ }^{1}$ The maps are taken from the Comprehensive Atlas of the Dutch United East India Company. Volume II. Java and Madura. Amsterdam: the Royal Dutch Geographical Society (KNAG), Utrecht University/Explokart (UU) and Asia Maior/Atlas Maior Publishers, 2007. The scale of maps in the book is presented in various scales. The 2005 map is taken from the municipality printed map in the original scale of $1: 1,000$.
} 
closely allied to the history of urban form and referred to as morphogenetic, allows understanding of the stage of development and process of the urban fabric. This approach firstly focuses on the important role of constants or the historically persistent elements, in the fabric of the city in determining the present configuration of the city evolving from one stage to the next. Secondly, it focuses on the relationship between building type and urban fabric over time (Levy 1999). The analysis of the evolution of buildings in Surabaya old district will show the continuity of distinct local typological process.

Such an analysis, involving the reconstruction of how buildings evolved in a given area, eventually giving rise to the buildings that predominantly today, is an essential tool for providing historical continuity when planning for future development in the historical district. From the reconstruction of the typological process, the rules and laws will be discovered through which the urban form developed and to which any new design must be related. These rules govern the place of buildings in the urban fabric-the relationship between buildings and plots, buildings and streets, buildings and their location in the street block, and finally the architecture of the buildings, such as types, plans, structures, facades, components, and materials. The more closely a future development follows these rules, the better it will fit in within the existing buildings; and in turn, forming the basis for future variations. Furthermore, to identify morphological changes, a simple technique is used to visually identify the location and extent of change is maps overlay. When examining change between two or more dates of maps, it is most commonly done by overlaying a scaled map as the base map for others to be overlaid.

\section{THE MORPHOLOGICAL DEVELOPMENT}

Surabaya was found in the fourteenth century based upon some historical accounts. The written evidence of Surabaya (Churabaya) as merely a village is in the Trowulan I epigraphy dated 1358 describing names of places used to across the Brantas river (Soekadri 1977: 9; Timoer 1983: 13). The other evidence is written in the Nagara Kertagama (part XVII, verse 5 of the last sentence) written by Prapanca in which Surabaya was one of the places visited by King Hayam Wuruk (1389-1452) in 1365 that states "...yan ring Janggala lot sabha nrpati ring Surabhaya manulus maring Buwun" [when visited Jenggala stayed in Surabaya and then advanced to Buwun]. However, Faber believes that Surabaya existed before the dates written in the inscriptions, the city was established in 1275 by King Kertanegara as a settlement for his soldiers in 1275 (Faber 1953: 7594). These accounts however were not used by the local government; the city's No. 64/WK/76 decree has decided May 31, 1293 was the birth date of the city. This account is based on the Prince Wijaya of the East Java kingdom of Singosari defeated a Chinese invasion army sent out by the emperor Kublai Khan in a village which located in Surabaya (Faber 1953).

\section{The North-South Axis Development}

In fourteenth and fifteenth century, Surabaya had been a major port in the regional level where various agricultural products such as sugar, coconuts, coconut oil, tamarind, garlic, onion and rice were exported to other islands of Borneo (Hikayat Banjar in Reid 1988:31). At the end of the fifteenth century, Surabaya was one of Majapahit's most important seaport that flourished with the population of at least 5,000 people (Diessen 2004). However, the city development was disrupted between 1625 and 1743 by the four wars that involved the city. ${ }^{2}$ The wars came to an end, and after another disruption of the Chinese rebellion in 1740, finally the city became the VOC possession on November 11, 1743 under the agreement between the king of Mataram Pakubuwono II and Governor General van Imhoff.

In the beginning of nineteenth century, Surabaya emerged as an important coastal port city in Southeast Asia where in 1811 according to Sir Samuel Auchmuty "The ship destined for the Philippines and for China generally touch at Sourabaye [Surabaya]" (Stockdale 1995). The city emerged as important port city because of its strategic location in the coast and the existence of the Kalimas, a river that played as major transportation system to transport people and goods from and to the hinterlands, as described that "The river is navigable for all the country coasters, of which it is always full. There are several small yards where they are built to draw ten and twelve feet water; they are sold to the princes of Borneo and Baly [Bali]; likewise others for transporting the produce of the neighbourhood, which is only rice" (Stockdale 1995).

\footnotetext{
${ }^{2}$ The wars were the annexation of the city by Sultan Agung (16131645) in 1625 (Graaf 1986:15); the battle between the Madurese prince Trunajaya and the VOC forces led by Admiral Cornelis Janszoon Speelman (1628-84) in 1677 (Ricklefs 1993: 37-39); the First Javanese War of Succession, 1704-08 (Ricklefs 1993: 129151); and the Surabaya war and the Second Javanese War of Succession from 1717 to 1719 (Ricklefs 1993: 168-187).
} 


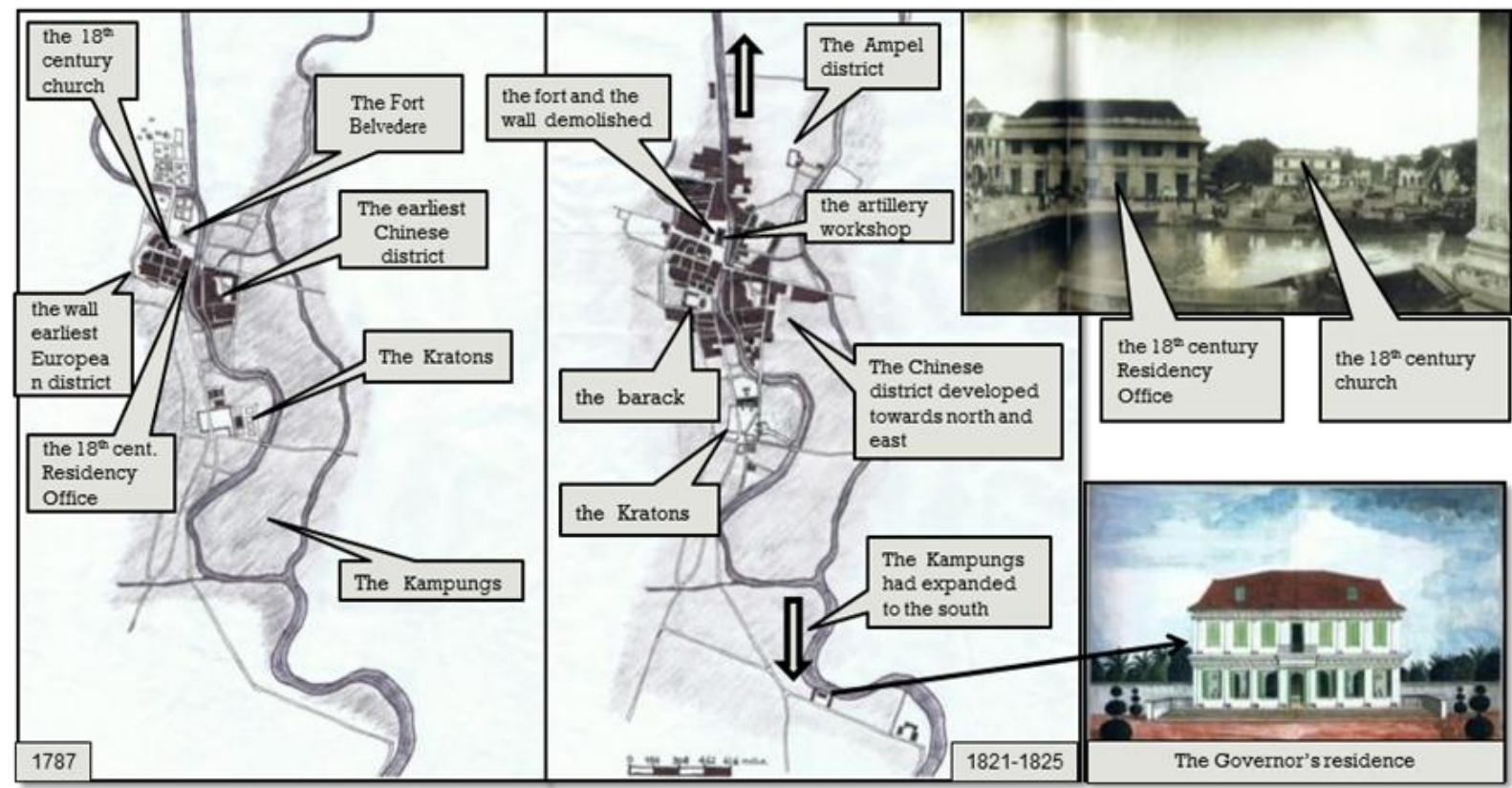

Source: the author

Figure 1. The morphological development of Surabaya, 1787-1825.

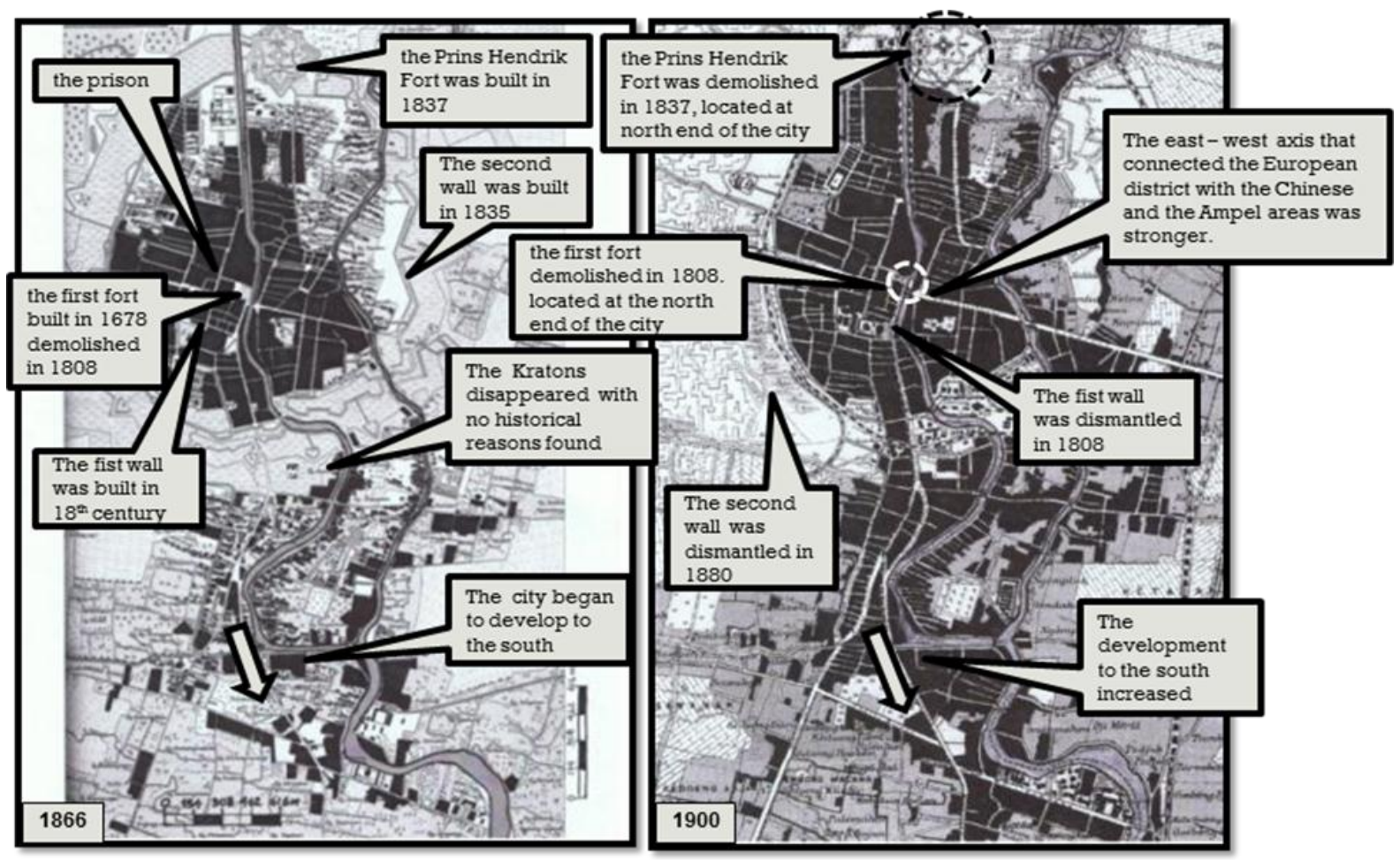

Source: the author.

Figure 2. The morphological development of Surabaya, 1866-1900.

Subsequently, the Kalimas had transformed the city that developed according to the north and south axis along the river (Figure 1). In 1809, the Great Post Road in Java had been completed at the command of Herman Willem Daendels (1808-1811). This military road has changed the urban form of Java's north coast cities and towns, where the road has reduced the cosmic power of the regent's palace by dividing the alun-alun (Nas 2001). In the case of Surabaya, the Great Post road has strengthened the north-south direction as the main transport system to other cities in East Java (Figure 2). 


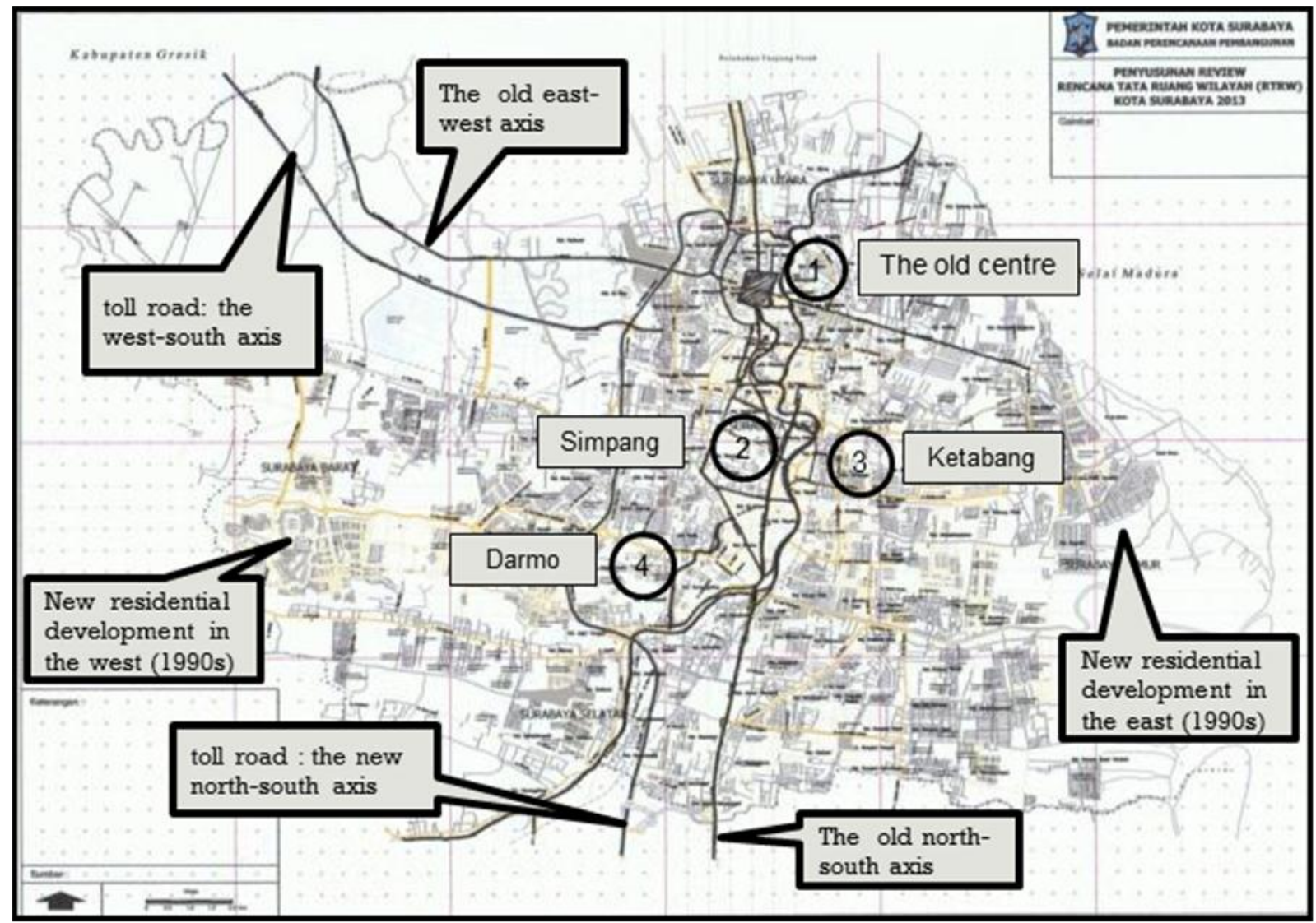

Source: Surabaya city map in 2010, RTRW 2015.

Figure 3. The north-south development of the city, 1910 - 1940.

This pattern of development continued to expand until the end of the colonial power (Figure 3). In 1910s, large scale residential development developed to the south mostly by the Dutch firms, rich Chinese and Arabs families. These new European middle class residential areas ended in 1920 because of the post-war recession, and recovered in 1927, and collapsed again in 1930 of the world depression (Dick 2002). The last residential development to this south direction was the Darmo area that developed in 1940s (Gill1995). Today, the north-south axis of the city is still the major development as a toll road is used to transport goods from the south to north heading the Tanjung Perak harbour (Figure 3).

\section{The Morphology Development}

Ethnic groups tend to claim distinct territories, in cities tendencies towards segregation in ethnic quarters creating an ethnic mosaic of distinct, but similarly patterned areas, organised by language group, ethnicity, occupation and district or even village of origin (Evers 2007). The distinct territories were seen in the old centre such the European quarter at the west side of the river, the Chinese quarter in the south and the Arabs quarter in the north part of the Chinese, this ethnic segregation was also intensified by the Dutch under the Wijkenstelsel (Figure 1).

\section{The Chinese District}

According to Faber (1931:76), the Chinese community has resided in Surabaya since 1411. However, it is noted that the first generation of the Chinese came to East Java and probably in Surabaya in the seventeenth century as in the case the Han Family (Salmon 1991; The 1934). The earliest settlement with the layout of grid pattern that developed in the Chineseche Voorstraat or Petjinan Koelon street was laid out facing along the river (water) that belief to brings luck to the community following the traditional settlements pattern of the ancestral port cities in Southern China (Widodo 2004). In this earliest period, obviously life centred in this area as the river was the major transportation mode for trading. The Chineseche Voorstraat was the main street in the area as described by The (1934) “... 
di "Djalanan Kampoeng Tionghoa" jang pada itoe tempat tjoema mempoenjai satoe nama sadja, di satoe djoeroesan. Ini straat adalah "Chineesche Voorstraat" atawa "Petjinan Koelon" jang sekarang To the south, the Chinese district was connected with a bridge to the Javanese Royal Palace, as stated by The (1934) that (Figure 1):

Boet sekarang itoelah ada di oetjoeng-oetjoeng dari Chinesechestraat (Petjinan Koelon) dan Tepekongstraat, di ini bagian ada terdapat satoe djembatan boet menjeberang Kali Mas (Kali Bibis) aken toeroen di mana straat jang menoejoe ka bagian kratonnya boepati.

This physical link was due to a close trading interaction between the Chinese and the Javanese rulers. The Chinese was the main rice traders and regularly came to the rice market that located near the Royal Palace where the Javanese rulers could conveniently inspected the rice trading as he was responsible to deliver 700 kojan of rice to the Dutch Indies Company (The 1934; Faber 1931). ${ }^{3}$ The location of the market near the Palace was also described by Valentijn as "Between the residence of the prince and the fortress of the Company, there was a large market place, where you can buy cheap article" (Faber 1931: 10).

In 1825 , the district started to develop to the south, east and north along both sides of the main road: Petjinan Koelon or Karet street today and Handelstraat or Kembang Jepun today. The settlement had fully developed within the city wall, and as the wall was demolished in 1871, the settlement continued to expand to the east (Figure 4). This area as the core of the Chinese area was also recognized by its main buildings, such as the prominent Chinese ancestral temples: the Tjoa, The Goan Tjing that located at 50 Karet street, and the Han families that located at 65 Karet street, and the Mazu temple (Figure 4, 5 and 6). ${ }^{4}$

\footnotetext{
${ }^{3}$ The weight of 1 koyan was approximately 1.482 metric tons, for a more detail description see Ricklefs (1993:238).

${ }^{4}$ The three families were the affluent family appointed by the Dutch as the Chinese community leaders. The first generation of Han family migrated to East Java in 1673, and many of them were appointed as majors, captains and lieutenants of the Chinese community in various cities of East Java, especially in Surabaya. Some of them, such as Ham Sam Kong (Soeroadinegoro) became a Muslim who merged into the Javanese elite as an Regent (Salmon 1991). The Goan Tjing (1795-1851) was the appointed major in Surabaya, and the ancestral temple was established in 1883 by four of his sons (Rumah Sembayang Keluarga The Goan Tjing 2001). The first generation of Tjoa family, Tjoa Kwie Sioe (1739-1793), married to Njai Roro Kiendjeng the daughter of the Surabaya Regent, Tumenggung Onggodjojo, and some of his descendants
}

The Mazu temple of Hok An Kiong is located at the end facing south to the Tapekong or today Coklat street, and the access to the temple came from the end of the street where the quay and probably the fish market were located (Figure 4). The layout is a typical Mazu temples site layout such as in Malaka and Pattani that follows the cosmological-geometric conception of boat (Widodo 2004). ${ }^{5}$ The masts of the boat were seen in front of the Mazu Temple in 1920s, today only the base remains (Figure 5). The temple was the oldest built by the Hok Kian Kong Tik Soe society and endorsed by the affluent Chinese, to name a few such as Ong Pan Liong, Major The Bone Hie, Major The Thwan Ing, Tjhoa Sin Hie, Lieutenenat Tan Tjien Oen, and Tjia Tjian Tiong, firstly for a resting place of the Chinese sailors (Widodo 2002).

The Chinese resided and did business in this core area in the shophouses built along the main roads of the Petjinan Koelon the Handelstraat. In this area, the retail trade had flourished to fulfil the needs of the whole community in the old centre, not only the Chinese but also the European as the retail trade was in the greater part of the hands of the Chinese and the Arabs (Faber 1931:123). After the 1880s of the dismantling of the city wall, the Chinese community expanded outside the old centre to the east side at the Kapasan area where another temple named Bun Bio was built, and to the southern part at which another temple was built at the Cokroaminoto area (Figure 2).

\section{The Elements of Persistent}

The town plan such as streets, blocks, and plots relatively remain the same, except for the graveyard had been occupied by the Bong market that named after the gravestone or Bongpay in Chinese (Figure 5). The major buildings such as the Mazu temple and the ancestral temples also remained; however, many shophouses had been changed by new buildings except for the remaining of few nineteenth century shophouses in the Karet street (Figure 6).

\section{The European District: the city for defence}

As early as 1617, the VOC (1602-1799) established a trading lodge in Surabaya, but it had to be abandoned in 1628 when it was attacked by Sultan Agung (Diessen 2004:7). In 1678, the construction of

were also appointed as the captains and lieutenants of the Chinese community (The 1934)

${ }^{5}$ The cosmological spatial configuration is the core settlement with a basic axis consisting of a Mazu temple and two masts at the one end, which face the harbour at the other end. 

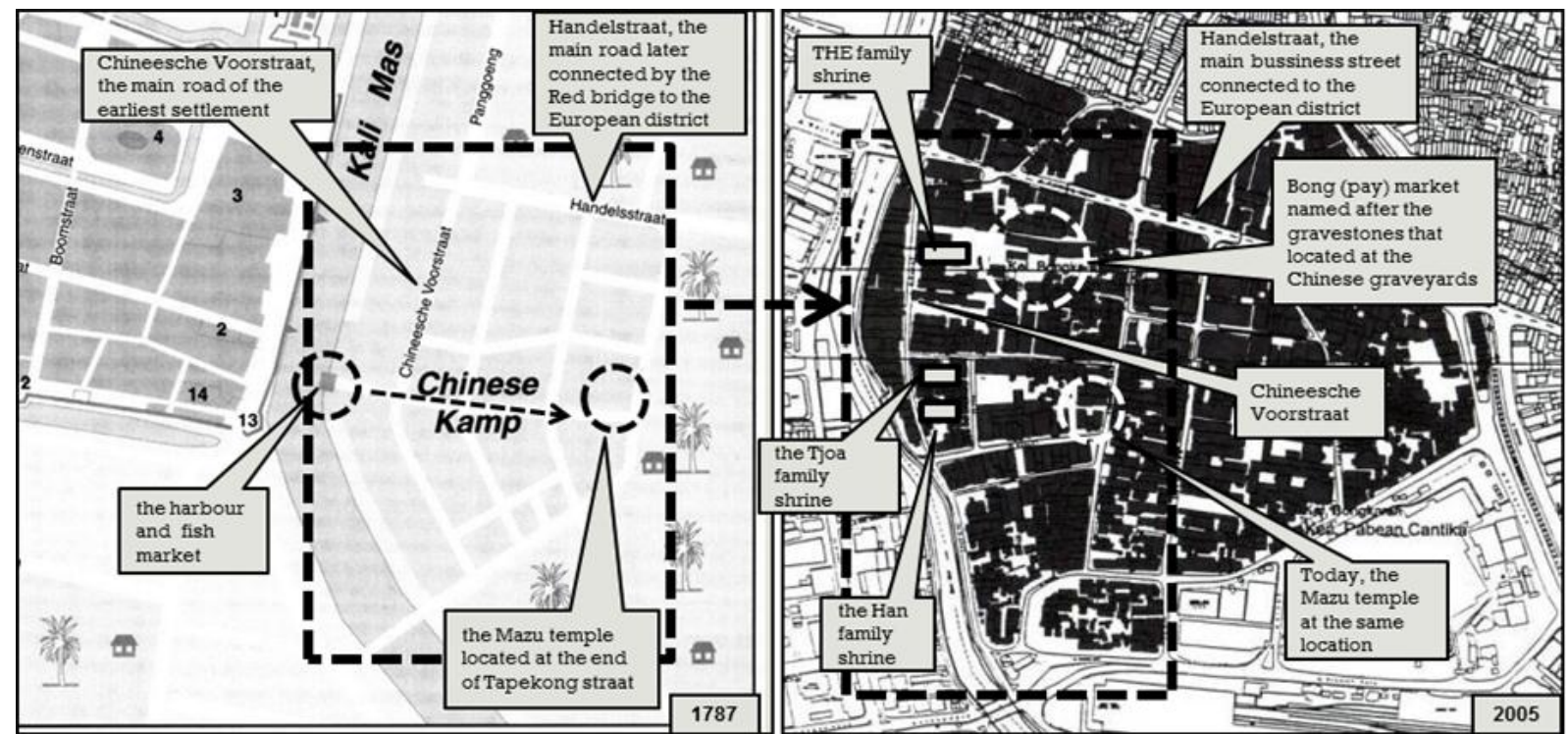

Source: the author.

Figure 4. The permanent elements of urban fabrics in the Chinese district.

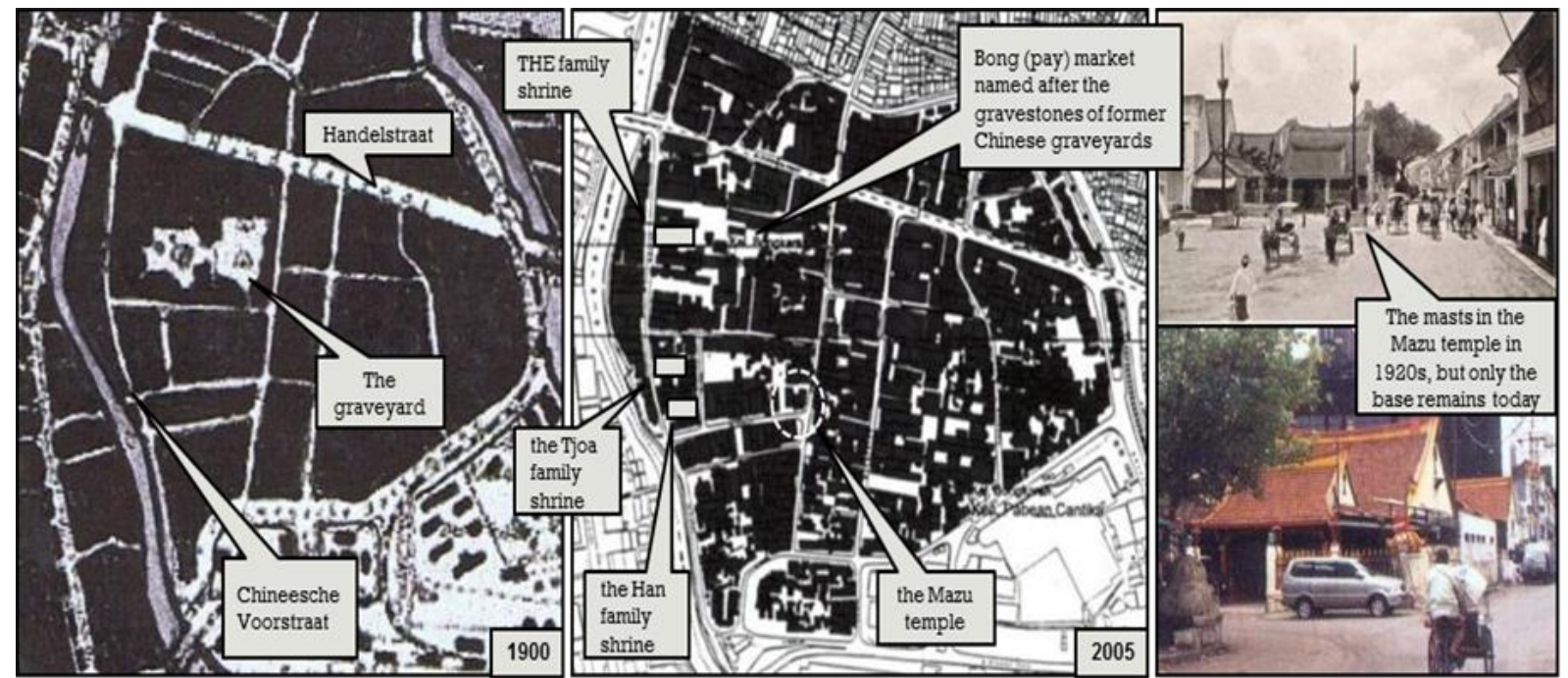

Source: the author.

Figure 5. The town plans of the Chinese district in 1900 and 2005, and the persistent elements.

a small fort named Providentie (later known as Fort Belvedere) was built on the left bank of Kalimas opposite the Chinese quarter, just after Speelmen's campaign against Trunojoyo in 1677. In few years later, a separated wall and canal accommodating the Company's commercial, administrative, military institution and its personnel was laid out just south of the fort. Both the fort and the town were enlarged several times in the eighteenth century, and reached the final size and form as shown on the 1787 map (Diessen 2004:7-8).

\section{The morphological development}

The Dutch settlement founded in 1743 with an area of 0.4 by $0.8 \mathrm{~km}$ was a typical Dutch colonial town plan that all Dutch colonial settlement had a common image in term of design and planning practice (Oers 2000). The earliest Dutch settlement such as in Surabaya had been founded and developed in six systematic steps as follows: the founding had the incentive of trade or war; the first constructions were of military origin: a fortified post or fortress, 


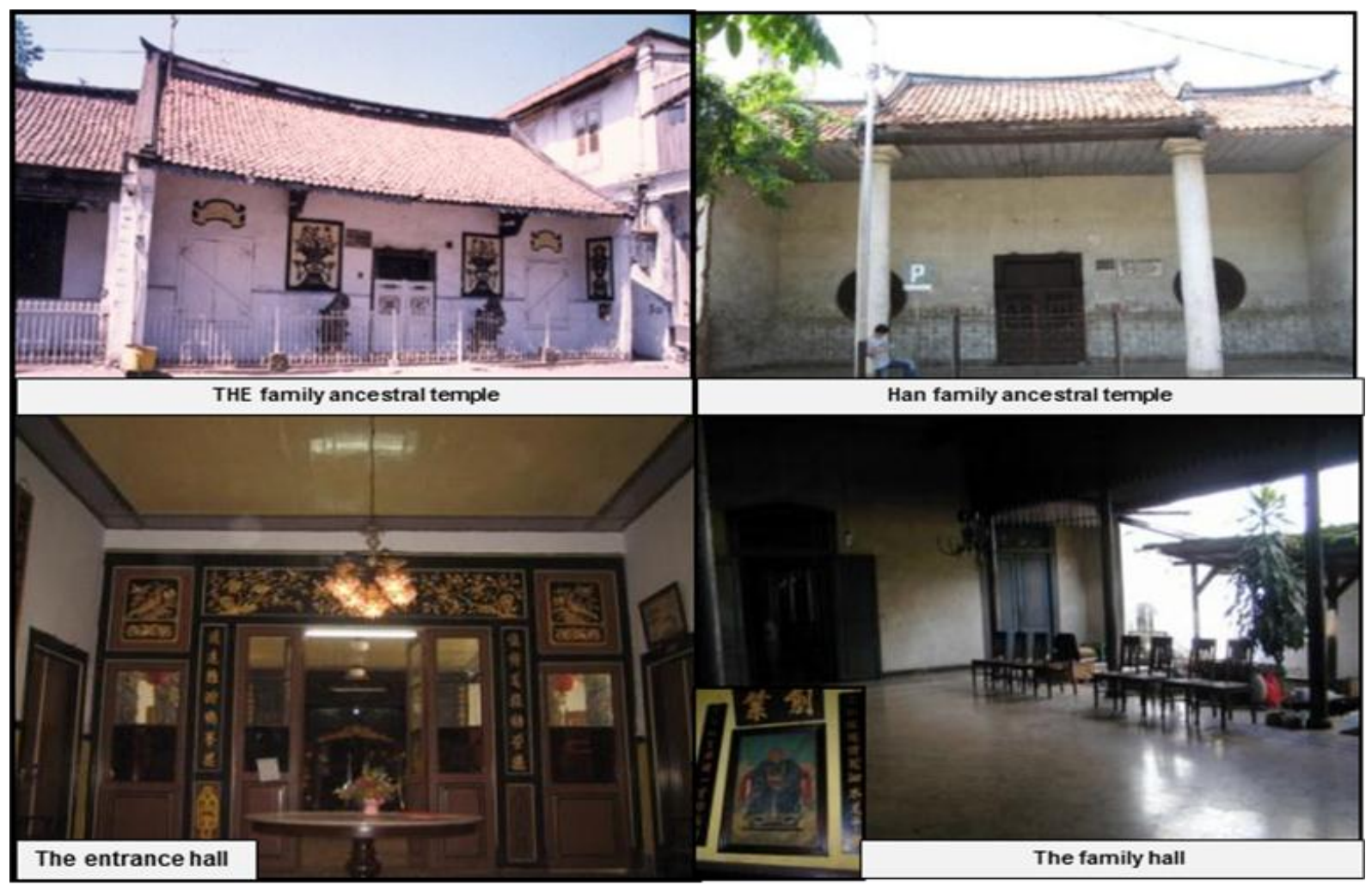

Source: the author.

Figure 6. The and Han family shrines of in Karet street.
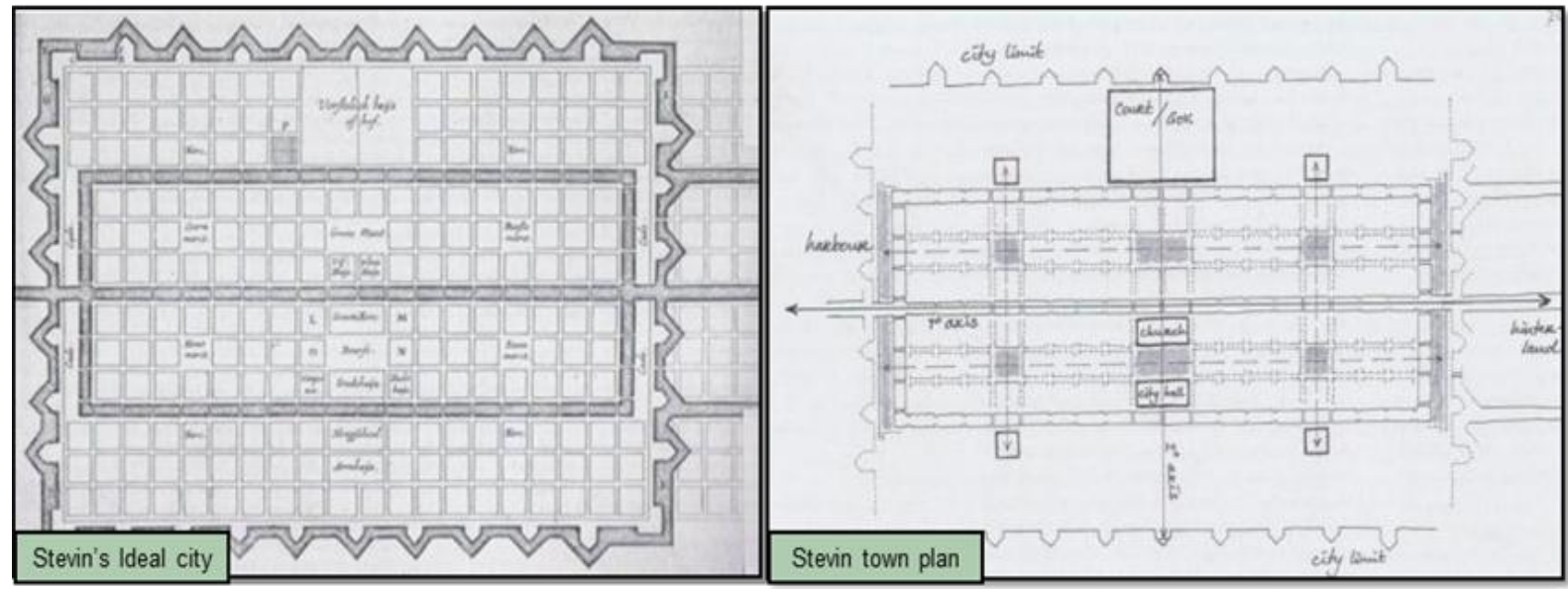

Source: van Oers (2000).

Figure 7. The town plan of the Stevin's Ideal City, and conceptual plan

later supplemented by redoubts, fortification walls or entrenchments; the design of ground plan to demarcate the newly conquered territory and to outline the future settlement followed; civil engineering were necessary to prepare the territory for occupation and habitation, such as after a landing stage or pier was built, then the terrain was cleared and levelled, drainage or canals, dikes, sluices and locks, bridges and wharves were built; the next was the establishment of infrastructure, such as a network of roads covering the main area of the occupied territory; and finally, building plots were outlines and buildings constructed, while a legal and administration system were established for the allocation and division of plots, ownership, and the organisation of the town.

The town plan of this earliest settlement followed the Ideal Scheme for a City written by one 
of the greatest Dutch scholar, Simon Stevin (15481620) that similar with a Roman army encampment that was built throughout the medieval Europe. As a camp-measurer of the Dutch States Army who made studies of the Roman art of war, his ground plan for the Ideal Scheme for a City was: a rectangular area enclosed by a fortification wall, with bastions at regular intervals, and the two bastions at each corner extend slightly outside the line of the fortifications to provide a better vision on the surrounding countryside and along the length of the wall; and the settlement has two distinct axis at the right angles of each other (figure 7).

The essential concept of Stevin's ideal city is (figure 7):

1. The central river or canal forms the primary axis of the ground plan; it runs from one side to the other side, from the sea to the hinterland through the settlement. This long line from harbour to hinterland represents continuity.

2. It is assume that, since the river or canal runs to the sea, the short side of the settlement is positioned parallel to the coastline. The settlement is accessible on both short sides where formal entrances and the quays of the inner harbour are located.

3. The city extensions are therefore positioned on these short sides of the settlement. Parallel to this primary axis run the city limits, the city walls or ramparts-the closed side of the settlement.

4. Perpendicular to the primary axis is the secondary axis that has its ends on bastions, against the closed sides of the settlement that represents discontinuity. This axis connects the most important social and public functions and spaces, including the centre of government.

5. The secondary axis gives structure to the inner organization; it provides position and orientation within the settlement, on a lower level of scale.

Applying this concept, the result of analysing the earliest Dutch settlement is as follows: the Kalimas river is the first primary axis that runs from the sea to the hinterland representing continuity. Since the river runs to the sea, the short side of the settlement is positioned parallel to the coastline. The settlement is accessible on both short sides where formal entrances are located, and the city extensions are therefore positioned on these short sides of the settlement, as the second primary axis runs from north to the south. Parallel to this first primary axis run the city limits, the city walls or ramparts-the closed side of the settlement. Perpendicular to the first secondary axis is the second secondary axis that has its ends on bastions, against the closed sides of the settlement that represents discontinuity. This axis connects the most important social and public functions and spaces, including the centre of government. The church in this case was the centre of the walled city (figure 8).

In the beginning of the nineteenth century, under Daendels' rule (1808-1811), the city grew as the centre of defence (Faber 1931: 23, 61; Diessen 2004:13)). He began with the demolishing the wall of the town and the Fort Belvedere, and replaced by two modern forts outside the town: Fort Lodewijk on the island of Menari near Gresik and Fort Kalimas at the mouth of the canal. The garrison was enlarged, and a new barrack complex was built at Djotangan area, located just outside the former southern town wall, and a new artillery workshop known as Artillerie Constructie-Winkel was built on the north side of the former fort. In the southern part of the city, on Simpang, Daendels rebuilt a mansion erected there in 1796 by the East Java administrator Dirk van Hogendorp (1794-1798) in a much grander style to fit its new function as the formal residence of the East Java ruler - in the later times used for the Residents of Surabaya and the Governor of East Java. In the same area, the Military hospital was built, which is now replaced by a shopping mall. All of these developments can be seen in the 1821-25 maps (Figure 1).

In 1820s, the city developed to the north and south outside the first city wall with the area of approximately more than twice the first one. The important phase of development was under the new general defence plan for Java implemented by GovernorGeneral J.C. van den Bosch (1830-1833). In 1835, the work of fortification the European town began, and two years later the Prins Hendrik Fort on the northern edge of the walled town was also constructed and completed in 1845. The town wall, however, was unfinished especially on the east side, and by then outdated as a rapid military technology development, then it was abandoned in 1871. Consequently, under the administration of S. Van Deventer (18681873), one important decision was to demolish the wall in 1880 (Faber 1931: 64; Diessen 2004:13). In 1895, the Prins Hendrik Fort was also dismantled (Figure 2). Another major building at that time was the new prison located in the Werfstraat or today Penjara street that built in 1848 and completed in 1850 with the cost of $f 60.000$ (Faber 1931: 73). In 1860s, there was a lack of housing as the increase of population in the walled town. In 1858, the Oostpost newspaper of June 3, 1858 described the increasing need of the European for housing and the extra ordinary rent price of houses (Faber 1931: 6162). Land supply was also limited in the old town; 

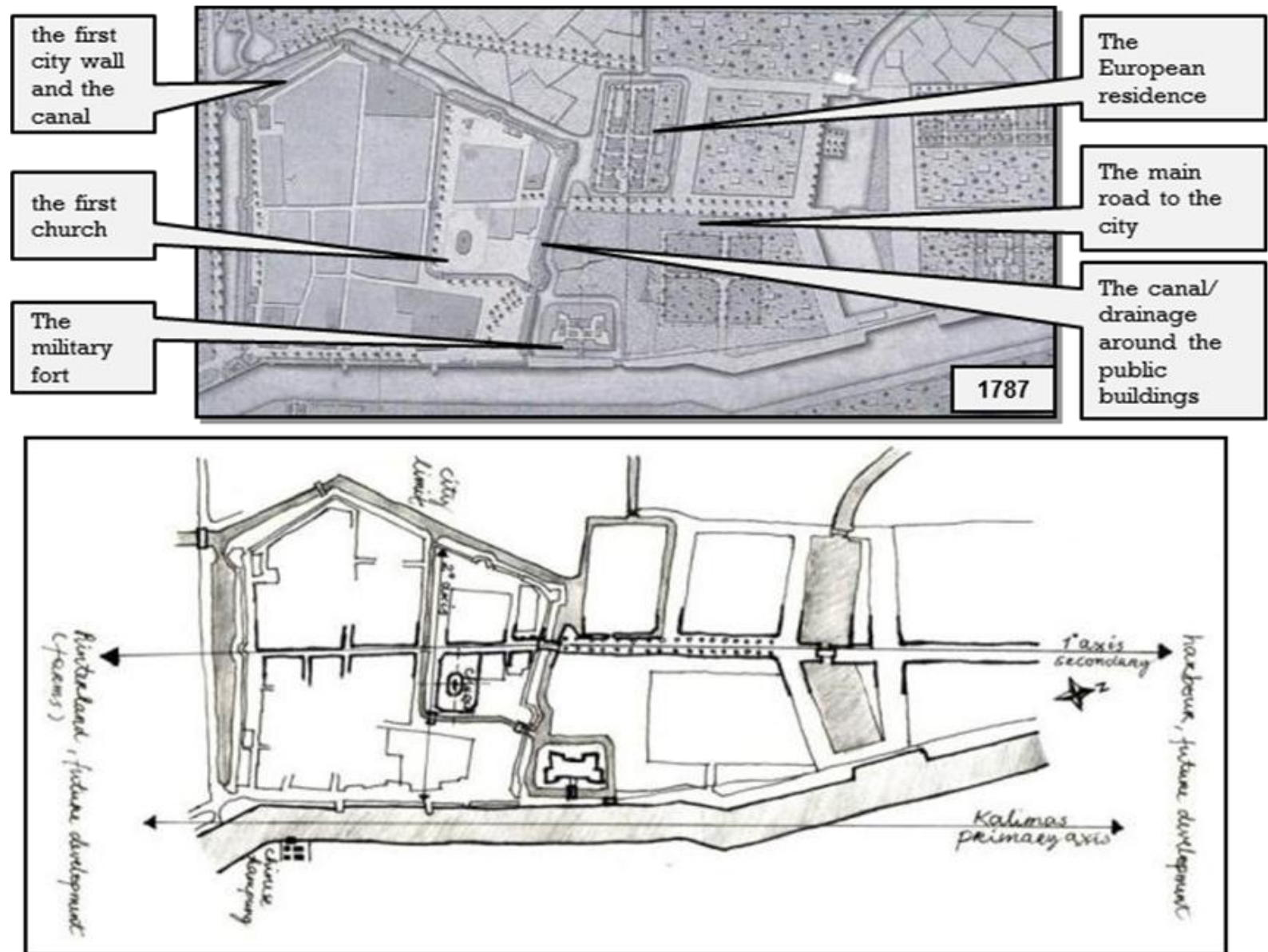

Source: the author.

Figure 8. The earliest town plan of the European district in 1787 was analyzed based on the Stevin's Ideal City.

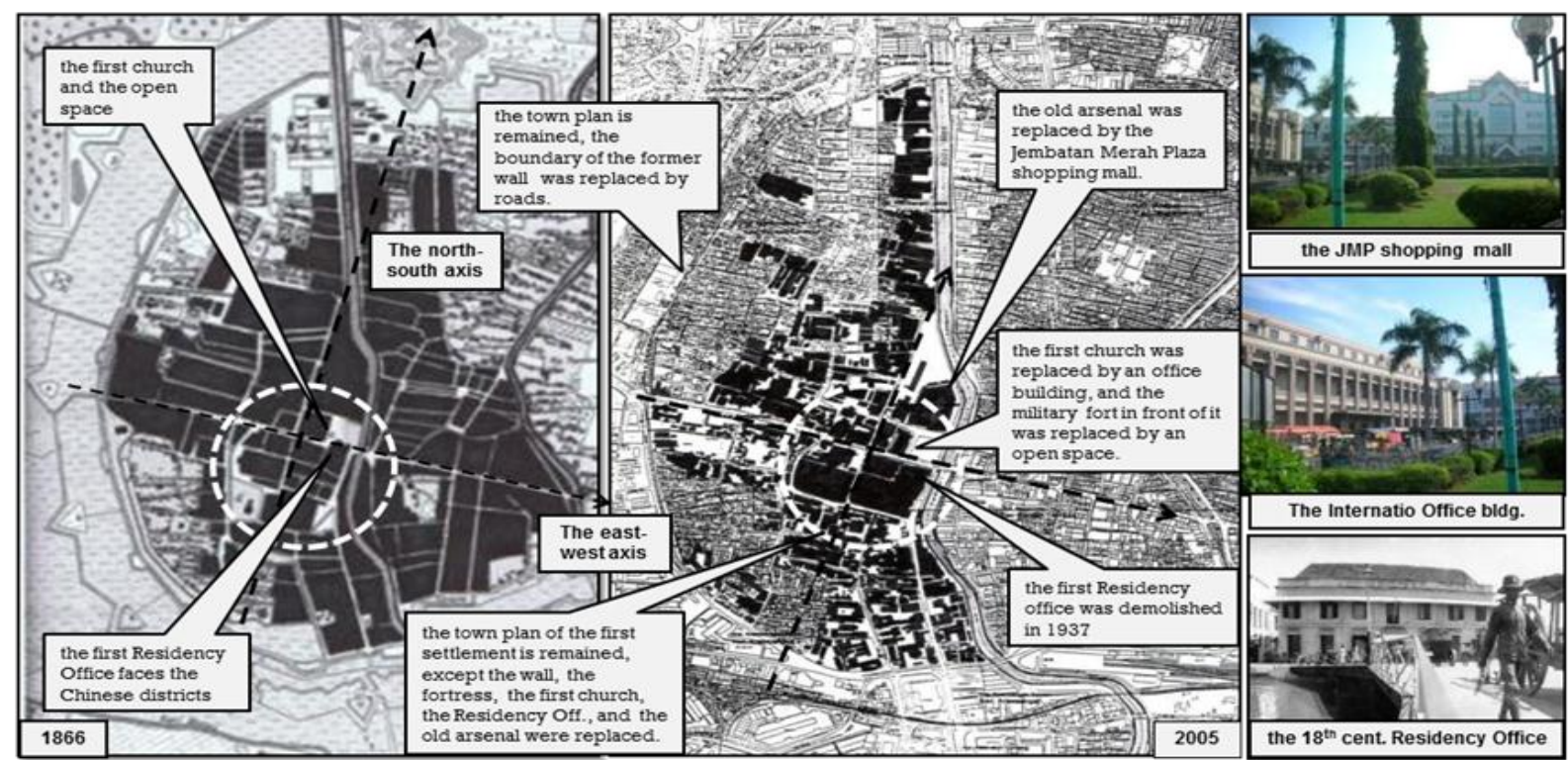

Source: the author.

Figure 9. The comparison between the town plan of the old European district in 1866 and 2005.

subsequently the town had to expand to the south outside the wall (Figure 2). In 1880, the dismantling of the second city wall had opened the city for opportunity to develop further in the south direction. 


\section{The elements of persistent}

The three urban form's elements had been transformed for decades. The first town plan of 1787 is remained, except for the boundary of the former wall was replaced by roads. Some major buildings also remain with different uses such as the barrack complex now used by the police headquarter and the prison known as the Kalisosok prison (1848-50) was now abandoned, however, the military fortress (16781808), the first church (1787-1929), the Prins Hendrik Fort (1837-1895), the first Residence hall, and the old arsenal were replaced. Today, the old arsenal was replaced by the Jembatan Merah Plaza (JMP) shopping mall. The first church was replaced by an office building, and the military fort in front of it was replaced by an open space (Taman Jayengrana). The first town hall was demolished, and it straightened the main road that connected to the main road to the Chinese district (figure 9).

\section{CONCLUSION}

The three aspects of historicity possess different degrees of persistent in the townscape. The town plan is the most durable element, as it is "the most conservative form complex, as its street system, and the associated plot pattern, is a fixed commitment of the whole urban community". The building fabric also shows a notable persistent though not the same degree as the town plan. It is somewhat less conservative, representing capital investment, and being subject to the natural processes of ageing, obsolescence and replacement. Accordingly, they could be adapted, rebuilt or replaced by new buildings. These two elements in particular form a morphological 'frame', constraining development to some degree, and land use patterns are rather more ephemeral.

In this respect, the morphological 'frame' of the old district of Surabaya quite conforms to the Conzen's notion, the town plan of the Chinese and the European districts show a notable persistence. It has remained intact in all essential features except for the demolition of the first and the second city's wall, and minor modifications of plot widths and street lines. However, the buildings fabric shows a drastic change, most of the nineteenth century the so-called Indische buildings have been replaced by the 1920s modern buildings especially in the main streets along the Hereenstraat and Willemskade in the European district, Chineseche Voorstraat and Handelstraat in the Chinese district. In 1990s, some of these buildings colonial buildings have also been replaced by new buildings.

The land utilization was certainly less persistent; however, there was a significant difference between the Chinese and the European district. For two decades, from 1787 to 1900 , the land use for residential, public facilities uses such as religious uses (temple); and commercial uses has relatively no changes. The commercial and residential uses in the form of the shophouses were mostly maintained in the main corridors and the rest of the area, and the temple remains in the same location. For the same two decades, the land utilization in the European district has changed dynamically. The first and the second wall of the city were replaced by roads, the first and the second fort were replaced by open space and residential uses, the $18^{\text {th }}$ century Residence Office was changed for a road, and even the first $18^{\text {th }}$ century church was replaced for a commercial use as a trading office. It is interesting to note that most of the changes in land utilization were land uses for defences, such as the forts, and the city wall.

This phenomenon was comprehended since the city was planned for defending its commercial objective of the VOC and later on the Dutch colonial power when the four wars had occurred during the period. In the beginning of the foundation of the city in the $18^{\text {th }}$ century, the Stevin's ideal city was implemented as the first fort and city wall was the major characteristic of the European district, in the end of the $19^{\text {th }}$ century the second fort, the Prince Hendrik, was also built with the same pattern located at the north end of the city wall.

In short, the quality of historical townscape, their historicity, rest largely upon the survival of their town plans and the remaining stock of historical buildings, and land utilization is a more minor, indirect, aspect of historicity. Buildings are exposed to changes, unfortunately this process working at random in the townscape, have gradually broken up the architectural unity of Surabaya old town. The result is the present intricate and irregular patter of period mixture in the building fabric, and the identity of the old centre is diminishing.

\section{REFERENCE}

Adishakti, Laretna T. (1997). "A study on the conservation planning of Yogyakarta historic-tourist city based on urban space heritage conception". Dissertation, Kyoto University, Japan.

Cobban, J. L. (1985) "The ephemeral historic district in Jakarta", Geographical Review, 75 (3), 300318.

Conzen, M.R.G. (1988). Morphogenesis, morphological regions and secular human agency in the historic townscape, as exemplified by Ludlow, in Denecke, D. and Shaw, G. eds. Urban historical geography: recent progress in Britian and Germany, 253-272. 
Corsini, M. Grazia (1997) "Residential buildings type in Italy before 1930: the significance of local typological process", Urban Morphology 1, 3448.

Dick, Howard (2002). Surabaya, city of work: A socioeconomic history, 1900-2000. Athens: Ohio University Press.

Diesen, J.R. van ed. (2004). Soerabaja 1900-1950: Havens, marine. stadsbeeld, port, navy, townscape. Zierikzee: Uitgeverij Asia Maior.

Evers, Hans-Dieter (2007). "The end of urban involution and cultural construction of urbanism in Indonesia", Internationales Asienforum, vol. 38: 1, pp.51-65.

Faber, G.H. von (1931). Oud Soerabaia, de geschiedenis van Indies eerste koopstad van de oudstetijden tot de instelling van der Gemeeteraad (1906). De Gemeente Soerabaia: G.H. von Faber.

(1936). Nieuw Soerabaia, de geschiedenis van Indies voornamste koopstad in de eerste kwarteeuw sedert hare instelling 1906-1931. De Gemeente Soerabaia: G.H. von Faber.

(1953). Er werd een stad geboren. De Gemeente Soerabaia: G.H. von Faber.

Frederick, William H. (1989). Visions and heat: the making of the Indonesian revolution. Athens: Ohio University Press.

Gill, Ronald G. (1995). De Indische stad op Java en Madura: En morfologische studie van haar ontwikkeling. Delft: Technische Universiteit Delft.

Graaf, H.J. De (1986). Puncak kekuasaan Mataram, politik ekspansi Sultan Agung. Jakarta: Pusaka Grafitipers.

Harastoeti DH (2005). "Strategi kegiatan konservasi bangunan bersejarah periode colonial di Jakarta, Bandung dan Surabaya". Disertasi program Doktor, Institut Teknologi Bandung.

Ikaputra (1995). "A study on the contemporary utilization of the Javanese urban heritage and its effect on historicity: an attempt to introduce the contextual adaptability into the preservation of historic environment of Yoyakarta". Dissertation, Osaka University, Japan.

Larkham, Peter J. (1996). Conservation and the City. London: Routledge.

Levy, Albert (1999), "Urban morphology and the problem of the modern urban fabric: some questions for research", Urban Morphology 3 (2), 79-85.
Logan, W.S. ed. (2002). The disappearing 'Asian' city: protecting Asia's urban heritage in globalizing world. New York: Oxford University Press.

Moudon, Anne Vernez. (1997). "Urban morphology as an emerging interdisciplinary field", Urban Morphology 1, 3-10.

Nas, P.J.M. ed. (2006). The past in the present: Architecture in Indonesia. Rotterdam: NAI Publisher.

. ed. (2002). The Indonesian town revisited. Singapore: Institute of Southeast Asian Studies.

(1997). The early Indonesian city. Leiden: University of Leiden. Retrieved from http://www. leidenuniv.nl/fsw/nas/pub_EarlyIndonesianCity. htm

. (1997). The colonial city. Leiden: University of Leiden. Retrieved from http://www.leidenuniv.nl/fsw/nas/pub_ColonialCity.htm.

Oers, R. Van. (2000). Dutch town planning overseas during VOC and WIC rule (1600-1800). Zutphen: Walburg.

Ricklefs, M.C. (1993). War, culture and economy in Java 1677-1726: Asian and European imperialism in the early Kartasura period. Sydney: Asian Studies Association of Australia and Allen \& Anwin.

Rumah Sembayang Keluarga The Goan Tjing, 18832001 (2001). Surabaya: Penyusun.

Salmon, Claudine. (1991) "The Han family of East Java entrepreneurship and politics $\left(18^{\text {th }}-19^{\text {th }}\right.$ century)", Archipel 41, 53-87.

Siregar, S. Aminudin. (1990). Bandung-the architecture of the city in development: Urban analysis of a regional capital as a contribution to the present debate on Indonesian urbanity and architectural identity. Thesis submitted to Department of Architecture, Urban and Regional Planning, University of Leuven, Belgium.

Soekadri, Heru. (1977). Dari Hujunggaluh ke Curabhaya. Surabaya: Laporan Ilmiah Anggota Tim Penelitian Hari Jadi Kota Surabaya.

Stockdale, J. Joseph. (1995). Island of Java. Hong Kong: Periplus Editions.

The, Boen Liong. (1934) "Riwajat Familie Tjoa", Majalah Matahari, Semarang.

Timoer, Soenarto. (1983). Mitos Cura-Bhaya, Cerita rakyat sebagai sumber penelitian sejarah Surabaya. Jakarta: Balai Pustaka. 
Widodo, D. Imam. (2002). Soerabaia Tempo Doeloe, vol. I and II. Surabaya: Dinas Pariwisata Surabaya.

Widodo, Johannnes. (1988). Chinese settlement in a changing city: An architectural study of the urban Chinese settlement in Semarang, Indonesia. Thesis submitted to Department of Architecture, Urban and Regional Planning, University of Leuven, Belgium.
(2004). The Boat and the City: Chinese Diaspora and the Architecture of Southeast Asian Coastal Cities. Singapore: Marshall Cavendish Academic.

Zahnd, Markus. (2008). Model baru perancangan kota yang kontekstual: kajian tentang kawasan tradisional di kota Semarang dan Yogyakarta: suatu potensi perancangan kota yang efektif. Yogyakarta: Penerbit Kanisius 